\title{
Teaching science as a cultural way of knowing: merging authentic inquiry, nature of science, and multicultural strategies
}

\author{
Xenia Meyer - Barbara A. Crawford
}

Received: 1 July 2009/ Accepted: 8 February 2011/Published online: 8 March 2011

(C) The Author(s) 2011. This article is published with open access at Springerlink.com

\begin{abstract}
Due to the growing number of students from populations underrepresented in the sciences, there is an intensified need to consider alternatives to traditional science instruction. Inquiry-based instructional approaches provide promise and possibility for engaging underrepresented students in the activities of science. However, inquiry-based instruction without culturally relevant pedagogy and instructional congruency, may not be sufficient to support non-mainstream students in science learning, and may even serve to challenge students' cultural ways of knowing. This conceptual paper suggests that aligning reform efforts in science education to the field of multicultural education would buttress efforts to reach underrepresented student groups in science. This includes providing culturally relevant instruction and instruction toward making the assumptions of science explicit, in particular. To this end, this paper draws from literature in multicultural education to propose that deconstructing science through instruction in NOS may support Latino, African American and English language learning students in science learning.
\end{abstract}

Keywords Inquiry - Underrepresented $\cdot$ Multicultural $\cdot$ Instructional congruency $\cdot$ Nature of science

\section{Resumen Ejecutivo}

El propósito de este estudio conceptual es abordar el problema sobre cómo apoyar a grupos de estudiantes de poblaciones marginadas en el aprendizaje y el incremento de su interés por la ciencia. Combinamos puntos de vista teóricos procedentes de la educación científica

\footnotetext{
X. Meyer · B. A. Crawford

Department of Education, Cornell University, 400 Kennedy Hall, Ithaca, NY 14850, USA

e-mail: barbara.crawford@ cornell.edu

Present Address:

X. Meyer $(\bowtie)$

Graduate School of Education, University of California, Berkeley,

4646 Tolman Hall, Berkeley, CA 94720, USA

e-mail: xenia.meyer@berkeley.edu
} 
y de la teoría sociocultural del aprendizaje, para proporcionar nuevas perspectivas sobre la enseñanza de las ciencias para estudiantes procedentes de diversas culturas. Para este propósito se describen las bases teóricas del conjunto de investigaciones y las referencias que fundamentan los enfoques basados en la enseñanza de la ciencia por indagación. Asimismo, discutimos cómo las diferencias de idioma, cultura y las visiones sobre el mundo, representan grandes retos para el aprendizaje de las ciencias. Con base en esto, sugerimos que la enseñanza de ciencia por indagación, por sí misma, resulta insuficiente para proveer las oportunidades necesarias en las cuales los estudiantes negocien sus formas de comprender la ciencia.

Presentamos una propuesta para enriquecer la enseñanza de las ciencias por indagación reforzándola con la enseñanza explícita de la Naturaleza de la Ciencia (Nature of Science I NOS). Este enfoque de enseñanza ha sido propuesto por diversos investigadores, sin embargo, nosotros vamos más allá de este proceso, y utilizamos las aportaciones de la educación multicultural, donde la enseñanza explícita de la NOS facilita el proceso de deconstrucción de la ciencia a la vez que enriquece e ilumina su marco. Es necesario aclarar el uso que le damos al término de deconstrucción de la ciencia, el cual no lo utilizamos como lo hacen las perspectivas socioculturales y feministas. En lugar de desafiar el poder, la autoridad, el acceso, y los hábitos relacionados con la ciencia, nuestro enfoque pretende desmitificar el marco de la ciencia y situar el conocimiento del contenido en ese marco, para permitir que los estudiantes, por sí mismos, consideren la ciencia en relación con otros modos de conocimiento.

La enseñanza explícita de la NOS podría a su vez crear oportunidades a los estudiantes para navegar a través de barreras culturales y para obtener un mejor entendimiento de las ciencias. Los enfoques para la enseñanza de la ciencias que tienen esta finalidad pueden servir de apoyo a los estudiantes que presentan bajo rendimiento en ciencias. En este trabajo, argumentamos que al sincronizar las reformas en la educación científica con el campo de la educación multicultural, se facilitarían los esfuerzos para incorporar a los grupos de estudiantes marginados de la ciencia. Para este propósito, primero establecimos una comprensión de la ciencia como cultura aunado con el potencial y las limitaciones de utilizar la enseñanza de las ciencias por indagación con estudiantes marginados. Posteriormente se discuten los límites sociolingüísticos y socioculturales, así como las barreras para el aprendizaje de ciencias y los distintos roles que el idioma, la cultura, las visiones sobre el mundo y la identidad pueden asumir.

Finalmente y desde el campo de la educación multicultural sugerimos que las oportunidades para la negociación de los límites y el cruce de fronteras dentro de la ciencia, pueden facilitarse a través de la participación en la actividad científica y las prácticas de enseñanza culturalmente congruentes. Varios investigadores puntualizan las deficiencias de los planes de estudio de ciencias con relación a la educación multicultural, los cuales no consideran las características específicas de la ciencia Occidental. Sin embargo, nosotros utilizamos los principios de la educación multicultural para atender dichas deficiencias. Mientras que estos principios sugieren la adopción de estrategias de enseñanza culturalmente congruentes, a su vez señalan la explicidad en la enseñanza como algo imprescindible. Ampliamos estas perspectivas para incluir el uso de la instrucción explícita de la NOS como una herramienta crítica que contribuye a desmitificar la ciencia. De esta manera, presentamos un nuevo enfoque híbrido de instrucción que reúne a la indagación y la práctica de instrucción congruente, incluyendo la enseñanza explícita de la NOS, para atender las diferencias culturales que forman parte de la enseñanza y el aprendizaje de las ciencias. 
The purpose of this conceptual paper is to address the problem of how to support diverse groups of students from underrepresented populations in learning and gaining an interest in science. We combine the theoretical viewpoints of science education and sociocultural learning theory to provide new perspectives on science instruction for diverse student groups stemming from multicultural education. To this end, we describe theoretical bodies of work and research studies providing support for embracing inquiry-based instructional approaches in science classrooms. However, we also describe how differences in language, culture, and worldviews may bring about challenges to science learning. Based on this, we suggest that inquiry-based approaches, alone, may fall short in terms of fostering opportunities for students to negotiate understandings about science. We will make the case for bolstering inquiry-based instruction with explicit instruction in nature of science (NOS) as an instructional approach, a view proposed by some researchers. However, we will push this case further, using the lens of multicultural education, where explicit instruction in NOS may facilitate a process of deconstructing science, or bringing its framework into light. Let us be clear that in using the term, deconstructing science, we do not use this term as it is used in socio-cultural and feminist perspectives. Rather than challenging power, authority, access, and habits related to science, our approach considers demystifying the framework of science and situating content knowledge within this framework to enable students to themselves consider science in relation to other ways of knowing. Better contextualizing science content matter within its framework and assumptions through explicit instruction in NOS may in turn, create opportunities for students to navigate cultural border crossings and negotiate understandings about science. Instructional approaches to this end may serve to benefit students who are underrepresented in the sciences. The ideas behind this conceptual paper originated in the personal classroom teaching experiences of the first author, when she taught science in a diverse urban school setting serving English language learning (ELL) students and students from multicultural backgrounds. In this setting the first author sought to bring inquiry into her classroom to engage students in science learning. Later, through reading the literature on situated cognition, she began to view participation in scientific activity, such as inquiry, as participation in scientific culture and science as a cultural way of knowing. The acknowledgement of science as culture, or a particular way of knowing that continually redefines itself and shapes and is shaped by the individuals that practice it, prompted her to consider the methods of supporting children in learning across cultures. Science as culture means that there are negotiated and accepted "rules of science," that it is empirical and that data drives the development of explanations; but also that society shapes the nature of the study and that scientists are humans with their own biases. These views on culture would also include everyday ways of knowing and school science as two separate cultures. Espousing these views on culture, the first author then conducted a parallel reading of the literature on sociocultural learning theory and multicultural education. Through these parallel readings, she began to look across these fields of literature, which oftentimes remain separate. In this space, she drew on instructional strategies from multicultural education to enhance science teaching and learning. This includes explicit instruction as a basic tenet. The second author has conducted research related to inquiry and explicit instruction in NOS (Schwartz, Lederman, and Crawford 2004) that provided a backdrop for infusing multicultural scaffolding into science instruction. Through this approach, we collaboratively considered the intersections of activity, context, and culture that may create moments of opportunity for scaffolding border-crossings within classroom-based science instruction.

In this paper, we argue that aligning reform efforts in science education to the field of multicultural education would buttress efforts to reach underrepresented student groups in 
science. To this end, we will first elaborate on establishing an understanding of science as culture and the potential and limitations of using inquiry-based instruction with underrepresented students. Next, we discuss sociolinguistic and socio-cultural boundaries and borders to science learning and the roles that language, culture, worldviews, and identity may assume. Last, we draw from the field of multicultural education to suggest how opportunities for negotiating boundary and border crossing into science may be afforded by engaging in scientific activity. Sherry Southerland (2000) points to the shortcomings of curricular multicultural science education in that it does not address the unique characteristics of Western science. We, however, draw on the tenets of multicultural education to address these very shortcomings. While many of these tenets suggest adopting culturally congruent instructional strategies, which are described further in detail below, they also they also point to explicitness in instruction as being imperative. We extend these perspectives to include using explicit instruction in NOS as a critical tool to help demystify science. The following four sections develop our argument: (1) Inquiry as Participation in Scientific Culture, (2) Science Learning as Cross-Cultural Education; (3) Scaffolding for Negotiating Science Understandings; and (4) Classroom use of this Instructional Approach and Student Responses.

\section{Inquiry as participation in scientific culture}

Science education has largely been unsuccessful in reaching ELL, Latino, Native American, African-American and other non-mainstream student groups, who remain underrepresented in the field of science. As stated by William Cobern, 'Science education is successful only to the extent that science can find a niche in the cognitive and sociocultural milieu of students' (1993, p. 57). The intent of the reform efforts advocating 'science for all' (American Association for the Advancement of Science [AAAS] 1990), followed by measures aimed at closing the achievement gap have worked to both open spaces and create constraints for the possibility of reaching students from underrepresented groups.

The AAAS initiative aimed to sweep significant change into traditional science classrooms, where instruction had mainly focused on students passively memorizing the facts of science. Increased attention on helping students learn how to 'do science' versus just reading about science, focuses on the processes of science and how scientists do their work. Another aspect of reformed-based science teaching involves 'talking' science, which signifies appropriating scientific discourse. This would include learning to apply the language of science within the space of scientific ways of knowing (Rosebery, Warren, and Conant 1992). An example of this would be learning to use the term "inference" within the scope of scientific activity, such as making inferences, rather than a vocabulary term. An additional aspect involves students learning about the nature of scientific inquiry, and that there is no single scientific method. While the reform efforts promote active learning and highlight aspects of inquiry into mainstream of science education, there is still much debate on what exactly, constitutes scientific inquiry in science classrooms.

In this paper we adopt the meaning of inquiry posed by the National Research Council (NRC). The NRC describes inquiry as 'the diverse ways in which scientists study the natural world and propose explanations based on evidence derived from their work' (NRC 1996, p. 23). Together, the diverse practices within the scientific community comprise a situated way of knowing. Inquiry in this case, is consistent with the activity component of situated cognition, where the interrelated activities, context, and culture of science 
construct scientific knowledge (Brown, Collins, and Duguid 1989). While inquiry is conducted within the authentic context of research, it is framed by the overarching cultural practices of science, or NOS. Inquiry is also described as, 'activities of students in which they develop knowledge and understanding of scientific ideas, as well as an understanding of how scientists study the natural world' (NRC 1996, p. 23). This perspective on inquiry lends itself to framing science and the work of scientists as a community of practice, and accessing scientific knowledge through participating in scientific activities and appropriating scientific culture (Wenger 1998).

Reforms stemming from these initiatives emphasize engaging students in doing science, through inquiry in active classrooms, rather than passively learning about it, in traditional primarily didactic classrooms. What we mean by the "doing of science" involves students engaged in thinking about the scientific questions, making sense of the data, and connecting their own explanations to scientific ideas, similar to what a scientist does. We want to be clear that inquiry-based teaching is often confused with simply a "hands-on" approach, or allowing students to manipulate materials and carry out the mechanical tasks characteristic of the work of laboratory technicians, without developing understanding of the nature of the creative work of scientists (Huber and Moore 2001). The key point here is that in doing science, students are doing the thinking and learning, and optimally, asking their own questions.

Rooted in constructivist thought, inquiry seeks to create opportunities for learners to engage in science and gain in-depth understanding by building on their previous ideas. By bringing inquiry-based science instruction into classrooms, school-based science provides the dynamic space for student participation in practices around science. Based on NRC's recommendations (2000, p. 29), this involves the teacher engaging the learner in the following essential activities: engages in scientifically oriented questions, gives priority to evidence in responding to questions, formulates explanations from evidence, connects explanations to scientific knowledge, and communicates and justifies findings. In this way, bringing inquiry into science classrooms would merge school science with the work of scientists, in ways different from traditional instruction. The importance of an authentic context when engaging children in inquiry in science classrooms is supported by studies conducted by the second author (Crawford 2000). Thus, inquiry may create the space to interconnect students' everyday experiences, school science, and the scientific enterprise.

A few research studies in classrooms have shown the practice of using inquiry-based strategies to have positive results with diverse and underrepresented students. For example, Ann Rosebery, Beth Warren, and Faith Conant (1992) designed an inquiry-based experiment for English language learning (ELL) students and measured the effects of this intervention on student science learning and language development. The researchers found that most students gained the ability to talk scientifically in their native languages through an inquiry-based instructional approach. Olga Amaral, Leslie Garrison, and Michael Klentschy (2002) studied the effects of an inquiry-based curriculum on the academic achievement of ELL students from mostly Latino backgrounds. Findings demonstrated an increase in student achievement in all domains of testing related to an increase in time exposed to the curriculum.

Though these studies demonstrate promise, certain students groups continue to be underrepresented in upper level high school science classes, science-related majors in universities, and science-related careers in the US (Lee and Luykx 2006). This trend persists despite extensive education reform efforts aimed at improving science achievement on both a national and international scale. Reasons attributed to the underrepresentation of population groups in the sciences are many and complex. Recent efforts to close 
the achievement gap and raise the science aptitude of students have mainly focused on increasing accountability and evaluation measures (Settlage and Meadows 2002). Without directing greater attention to students' actual experiences in school science and how science may or may not align with students' diverse racial, cultural, and linguistic backgrounds and understandings, these student groups will likely remain underrepresented in the sciences.

While inquiry-based instruction may afford increased opportunities for engaging all kinds of students in science learning, there is a need to better conceptualize the challenges that students continue to face. While anthropological researchers point to a divide between students' ways of knowing and schooling (Lipka, Mohatt, and the Ciulistet Group 1998), sociolinguists point to the differences between everyday ways of knowing and science (Warren, Ballenger, Ogonowski, Rosebery, and Hudicourt-Barnes 2001). Still other educational researchers point to the disconnect between school science activities and the scientific enterprise (Brown et al. 1989). Inquiry, by contrast seeks to bridge these domains. Nonetheless, inquiry and scientific practices may not align with the cultural habits of all students. The tenets of inquiry, such as engaging in questioning and problem-solving, may in fact collide with other culturally accepted norms, such as accepting the knowledge of teachers or community elders (Lee 2003).

Our approach involves viewing science as culture, or a dynamic and negotiated way of knowing that is practiced by a particular community, and drawing from the field of multicultural education to suggest instructional approaches that support students in negotiating their understandings about science. In the next section we unpack our theoretical approach and describe our rationale. To this end, we utilize sociocultural theory in science education to highlight the cross-cultural challenges of science learning. We then suggest how instructional strategies drawn from the field of multicultural education and infused into science teaching and learning may support students in navigating the cultural divides between their everyday life-worlds, school, and school science.

\section{Learning science as cross-cultural education}

Science education literature provides explanations for how the cultures of science, school, and students may or may not converge in the space of school science learning at various scopes. In looking across these scopes, science learning would entail a student engaging in the culture of science within the culture of school, a perspective largely not addressed. This might seem an incommensurable project, without greater recognition for culture as dynamic, fluid, and constantly shifting (Gutierrez and Rogoff 2003). For example, science exists in dynamic space of negotiation, where procedures can be points of contention, and findings can be challenged by new pieces of information. Moreover, the scientific community remains in a continual debate in relation to what counts as rigorous research along the lines of differing theoretical paradigms and methodological approaches. Schools also entail a negotiated space of accepted practices, including school science, which rarely alludes to the actual practices of science. Meanwhile, school is a place where students can bring their cultural experiences that shape their habits and ways of knowing. In framing science learning as multi-tiered interaction between students, schools, and the scientific enterprise, a greater focus can be directed toward what schools and students bring to this process. This is significant, in order to view learning as a sociocultural and dynamic exchange of differing ways of knowing. In this way, the intersection of the cultures of students, schools, and inquiry-based science become moments of opportunity for 
negotiation of ideas, if addressed. Viewing science as culture creates the space for examining science learning, and inquiry, as a borderland of cultural interaction. As Driver, Asoko, Leach, Mortimer, and Scott (1994) explain, 'the view of scientific knowledge as socially constructed and validated ... means that learning science involves being initiated into scientific ways of knowing' (p. 6). Moreover, science learning becomes a 'process of enculturation rather than discovery' (p. 11). Along these lines, learning science becomes an appropriation of the activities, context, and culture of science (Brown et al. 1989). Interestingly, as described above, recognition of the cultural components and norms of science, such as argumentation (Lee 2003), may offer perspective for examining the challenges that underrepresented students face in learning science.

Interrelated linguistic and cultural challenges to science learning may persist despite innovative instructional approaches designed to engage students in the activities of science. For certain student groups, school science becomes a form of cross-cultural education. To these students, 'science is a second culture, in much the same ways as American educators speak of English as a second language for some students' (Cobern 1993, p. 58). In these spaces, the cultural components of science may be foreign to students and must be included as a part of science instruction. Science teaching thus needs to address both scientific content-matter and the framework upon which it is based, or scientific ways of knowing.

Viewing science as a cultural way of knowing acknowledges that it is laden with cultural understandings, interpretations, and a language of its own. For example, "Whenever pupils enter the world of school science, it soon becomes evident that science too is another culture with which s/he has to interact, bringing with him/her the other baggage of cultures s/he already carries" (Jegede and Aikenhead 1999, p. 45). For example, science learning may become particularly challenging when the cultural practices of the scientific community may or may not align with the cultural understandings of students (Lee 2003). These understandings include language and culture and play an integral part in shaping student identity and worldviews, or frameworks of ideas and beliefs through which individuals interpret the world and interact with it (Cobern 1993). These concerns translate to classrooms serving students underrepresented in the sciences. Angela Calabrese Barton and Edna Tan (2009) describe this as the conflicting nature of school science and the everyday understandings of students from nondominant cultures. In this case, school science, becomes yet another cultural border for students to cross, amongst the other challenges contributing toward the differential achievement of students in schools (Aikenhead 1996).

Sociocultural perspectives are thus essential to understanding the challenges of science learning for underrepresented students and the moments of possibility in achieving crosscultural understanding. Sociocultural theory opens the space for examining challenges to science learning as being bounded by cultural boundaries and borders. Erickson (1993/ 1996) refers to the ability of students to negotiate differences in cultural understandings in schooling by moving through cultural borderlands, or the space of negotiating cultural understandings, by way of traversable boundaries or more rigid borders. Whereas boundaries refer to cultural differences in practice, such as communicative patterns, borders are social constructs across which power is exercised. Borders comprised of epistemological differences create deeper divides between cultures than linguistic differences. For example, worldview differences may be likened to a border. Moreover, power differentials set by borders in schooling and teacher-centered instructional approaches may limit the negotiation of cultural differences and understandings and thus may bring about resistance to learning. 
We apply these same constructs to describe challenges to science learning for diverse student groups. Whereas we frame the differences in cultural communicative patterns as boundaries to science learning, we delineate deeper epistemological differences as borders to science learning. For example, if challenges to science learning are comprised of linguistic differences, instructional adaptations such as linguistic scaffolding may facilitate a student boundary crossing, If students' cultural ways of knowing are marginalized within the school practices of science learning, then one way of knowing effectively exercises power over another. Without culturally relevant instructional practices aimed toward facilitating student border crossing between cultural ways of knowing and science, by framing science within its ways of knowing, science instruction incurs a form of symbolic violence, where one way of knowing dominates and seeks to replace others. Because school science instruction focuses on only one way knowing, this is the case in school science teaching and learning. Students with other ways of knowing may be forced to abandon home, cultural, everyday, and other ways of knowing to be replaced by accepted views of science and knowledge production (Lipka et al. 1998). We suggest that infusing multicultural education strategies into science classrooms may present opportunities for negotiating boundary and border crossings into science. Moreover, we advocate for explicit instruction in NOS as an integral component of science instruction and part and parcel of a multicultural approach.

\section{Scaffolding instruction to support students in negotiating science understandings}

\section{Negotiating boundaries related to science}

As described above, our work considers cultural differences, such as communicative patterns, as potential boundaries to science learning. Several bodies of research relate to language-based differences affecting science learning for underrepresented students. This research represents multiple perspectives on the relationality of students, their linguistic abilities, and science, in light of students' participation in scientific investigations. For example, research related to the Chèche Konnen project directs attention to science learning through the use of students' native and everyday languages (Warren et al. 2001). Other research directs attention to English language acquisition through participation in inquiry-based activities (Stoddart, Pinal, Latzke and Canaday 2000). However, Okhee Lee's work additionally considers the linguistic and cultural support needed by students engaged in inquiry-based science. The principles introduced through her work reach beyond instructional approaches for ELL students, but rather are inclusive of teaching practices to help all students succeed (Ladson-Billings 1995).

Lee and Fradd (1998) contend that science learning is inaccessible to non-mainstream students through inquiry without further instructional support. 'Traditionally, science has been taught with the expectation that students will understand and learn when teachers present the content in scientifically appropriate ways... little consideration [has been given] to students' literacy, language, and cultural understanding' (p. 12). Lee (2003) further argues that not only do students need linguistic scaffolding, but students' cultural norms must also be brought into inquiry-based instructional settings. Also, inquiry may present particular challenges for students from cultural backgrounds that may not embrace some of its major tenets, such as argumentation, questioning, and student-centered instruction that shifts teachers into the role of learning facilitators rather than sources of information. Given differences in cultural expectations for learning environments, inquiry 
strategies by themselves, cannot be expected to assist students in science learning. Rather, instructors must consider framing science instruction and the activities of science in ways that are accessible to underrepresented and non-mainstream students. Drawing from the field of multicultural education may support students in navigating some of the boundaries established by linguistic and cultural differences.

Lee and Fradd's (1998) seminal work that considers non-mainstream students' interaction with language and the culture of science provides a framework for increasing the accessibility of science instruction. Rather than assuming students' appropriation of language and scientific understandings through participation in scientific activities, the researchers direct attention toward modifying instruction to fit students' existing tools for mediating learning. They build on the construct of cultural congruency, where instructional methods are aligned with students' cultural understandings and uses of language, to offer a framework for instructional congruency in science education. Cultural congruency entails adapting instructional practices to bridge between cultural differences. This could include infusing literacy learning strategies into content-area instruction, or drawing examples that can relate to students' diverse backgrounds. Instructional congruency, however, applies the construct of cultural congruency to a specific area of instruction, such as science education. Lee (2004) explains cultural congruency entails 'teachers integrat[ing] academic disciplines with students' linguistic and cultural experiences to promote academic achievement' (p. 66). However, instructional congruency entails teachers mediating between specific content matter and students' cultural backgrounds as an instructional approach. In Lee's words, instructional congruency 'combine[s] consideration of students' cultural and linguistic experiences with attention to the specific demands of academic disciplines' (2004, p. 67). For example, when it comes to science education:

Instructional congruence aims to help students acquire scientific understandings, inquiry practices, and discourse by taking into account the relation of these three domains to students' home culture and language, and by devising instructional strategies that address both the discontinuities and the continuities between the two broader bodies of knowledge (i.e., school science and students' prior linguistic and cultural knowledge). (Luykx and Lee 2007, p. 425)

Luykx and Lee (2007) introduce the instructional congruency framework as a tool for evaluating the cultural congruency of classroom science instruction. The framework considers the following in science instruction: (1) a sharing of scientific authority, (2) a diversity of cultural experiences and materials, (3) the use of students' home languages in classrooms, and (4) the use of linguistic scaffolding to enhance meaning. An instructional approach deeming to meet these components of instructional congruency in science focuses on mediating science content with the linguistic and cultural experience of students. This would mean intentionally pointing out the differences and similarities between the two as an integral part of instruction. For example, this could include integrating student cultural artifacts into science instruction and assisting non-mainstream students mediating differences in language and culture. Traversing across these spaces as a part of instructional practice, may in turn make science learning more accessible and meaningful for students. In this way, the instructional congruency framework may serve to model the negotiation of scientific and cultural understandings with students' use of home language to gain understanding. Moreover, it entails a student-centered approach to instruction, where students share the process of engaging in constructing scientific explanations. 
Together, the components of the instructional congruency framework align science reform efforts involving inquiry-based instruction with research in both science and multicultural education. Primarily, encouraging the sharing of scientific authority entails a shift from traditional teacher-centered instruction to a student-centered approach (Crawford 2000). In this shift, teachers take on a multitude of roles including that of a learning facilitator rather than the primary source of knowledge. The sharing of scientific authority is also an integral part of inquiry-based instruction. In this way, the instructional congruency framework encourages the use of inquiry. Further components of the framework align with research in multicultural education. For example, bringing diverse cultural experiences and materials into a classroom invites and validates students' cultural backgrounds. This aligns with a "funds of knowledge" approach, or drawing from the home experiences, ways of knowing, and cultures of students in the classroom (Gonzalez et al. 2005). Moreover, encouraging the use of home languages in science classrooms reflects the research-based findings of the Chèche Konnen Project described above. In using home language or everyday language during instruction, students are not detracted from contentmatter instruction (Nieto 2004). This is particularly relevant to all students when recognizing the language of science as a language apart from everyday language (Warren et al. 2001). Research on English language development supports using linguistic scaffolding to enhance meaning (Cummins 2000). Moreover, linguistic scaffolding could include making language switching codes between science and everyday language explicit to other students. For example, teachers would ask students, 'how would you say that in scientific terms?' In this case, in making the language of science explicit, teachers would support students in making boundary crossings into science by learning when to use scientific language apart from everyday language. With the aid of linguistic scaffolding, students would be supported in learning both science and language. In this way, the framework for instructional congruency combines the mediation of scientific and cultural understandings with students' use of home language to negotiate boundaries in science.

Similarly to Lipka et al.'s (1998) work with Yup'ik students in Alaska, the instructional congruence approach enacts a 'both/and' approach rather than an 'either/or' approach. It aims to assist students in recognizing differences between scientific and home cultures, without marginalizing the latter of the two. Through the cultural validation and added language-based support with instructional congruency, science learning can be likened to negotiating a boundary crossing. This would entail students' recognition when the application of the schema related to either scientific or home-based cultural paradigms is appropriate, This instructional approach presents a significant point of departure from traditional instruction and would serve to bolster inquiry-based instruction, as described above. Nonetheless, the instructional congruency framework falls short of considering more deeply set cultural and worldview differences. While the framework may support students in negotiating linguistic and cultural boundaries, it does not address borders to science that may be established by differences in worldviews and how these worldviews are positioned in relation to dominant understandings about science. In the next section we discuss explicit instruction about science itself as a pathway toward extending a 'both/and' instructional approach to support students in gaining understandings in science while maintaining their own cultural identities.

Negotiating borders related to science

Sociocultural views of science education extend the notion of cultural congruency to include epistemic and worldview perspectives. Science instruction may become culturally 
incongruent for non-mainstream students with epistemic differences and contradicting worldviews (Jegede and Aikenhead 1999). In other words, not only may cultural differences in practice, such as inquiry, serve to challenge certain students, but also differences in underlying frameworks for understanding. These cultural differences constitute borders to science education and are rooted in the lack of opportunities to negotiate and mediate between differing understandings about the nature and scope of scientific knowledge, power differentials, and identity. Students that continually experience challenges to their world-views, or everyday and culturally-based understandings of the world, as a result of science instruction may resist science learning.

As Jegede and Aikenhead (1999) describe, 'for a majority of students, science teaching is experienced as an attempt to assimilate them' (p. 48). For example, even instructional approaches through inquiry have mostly neglected science learning from students' perspectives. Though inquiry-based instruction targets mechanisms through which the learner can gradually become a part of the school science community and ultimately, the scientific community should they choose, the milieu of the learner is not addressed in this process. While students' participation would assist them in acquiring scientific knowledge, skills, and understanding as they engage with the scientific community, this relationship is unidirectional. The learner is brought into a community, rather than given the opportunity to establish a reciprocal relationship of shared understanding. Moreover, little is known about the process of negotiating scientific understanding from the perspective of the learner. Though inquiry builds from student background understandings, the approach does not offer the space to address students' cultural understandings and how they may or may not intersect with the culture of science. In this sense, inquiry-based instruction must be framed in an accessible way to students, and cannot, by itself, be expected to assist students in science learning. For these students in particular, science learning does not entail cultural congruency in a deeper sense where epistemic underpinnings and worldviews align. This is because 'a cultural perspective recognizes conventional science teaching as an attempt at enculturation or assimilation-cultural transmission that supports or replaces a person's life-world subcultures respectively' (Aikenhead 1996, p. 20).

Similarly to literature on cultural borders, where power differentials are at play in a borderland interaction (Erickson 1997). Aikenhead (1996) draws attention to cultural borderlands in science learning. However, he does not draw the distinction between traversable boundaries and rigid borders in his work. Rather, Aikenhead frames the rigidity of the border in science education based on its relationality to the learner. For example, if students come from cultural backgrounds that align with scientific ways of knowing, science instruction will uphold their worldviews. However, if students come from cultural backgrounds that do not align with scientific ways of knowing, science instruction may challenge students' worldviews.

In this way, science learning may be more accessible to student groups whose cultural ways of knowing align with scientific culture and less accessible to students from backgrounds that are underrepresented in the sciences. This is because science learning is implicated in Western ways of knowing, an already accepted cultural norm for many mainstream students. However, science instruction may involve cultural borders when it becomes 'subtractive', or marginalizes the world-views of students in relation to Western modern science. This is especially evident in science instruction for indigenous groups (Cobern and Loving 2000).

Researchers propose several suggestions for easing the cultural border crossings of students in science education. For example, Aikenhead (1996) emphasizes the importance of teachers supporting students in border-crossings into science. This includes that teachers 
acknowledge the differences between science and the everyday-worlds of their students. Further, that they consider instructional approaches to bridge these disparate worlds in order to make science curriculum accessible to their students. To this end, he combines the work of several anthropological theorists to point to the role of educators as 'tour-guides' into the world of science in relation to their students, who may have varying degrees of border-crossings. A teacher may act as a coaching apprentice, travel-agent culture broker, or tour-guide to a student who is experiencing border crossing experiences into science.

Jegede and Aikenhead (1999) describe collateral learning, where 'conflicting schemata [related to science learning are] held simultaneously in long term memory' (p. 52), as a function of successful border-crossing. Rather than undergoing enculturation and assimilating to views of science, collateral learners adapt different responses to the epistemological challenges of science. These learners engage in science learning through anthropological approaches, where science is studied but may or may not be incorporated into their cultural ways of thinking. Alternatively, students may undergo autonomous acculturation, where scientific and cultural ways of thinking coexist and are not disputed. In either case, a negotiation of cultural identity does not become part of the process of science learning. Identity and science learning remain separated. Moreover, students do not cope with challenges to cultural understandings by actively resisting science learning in these scenarios. Given support toward recognizing the cultural components of science and adapting a 'both/and' approach, border crossings may become accessible to students with worldviews that differ from those of science. These students may include girls, Latino, Native American, and African American students, who remain underrepresented in sciences, as well as ELL students.

Though both traditional and alternative forms of science instruction in schools are implicated in learning Western modern science, inquiry has potential to engage students in the activities of science. Because activity reflects the cultural practices of a community, an inquiry approach using authentic investigation could involve students in scientific culture. This, in turn, may increase the accessibility of science for these students. Inquiry would thus afford greater opportunities for the negotiation of epistemic stances and worldviews as related to Western modern science.

Nonetheless, the negotiation of understandings cannot be accomplished through inquiry alone, as described above. Lee (2003) suggests explicit instruction as a pathway towards both boundary and border crossings in science education. She insists 'ELL students need explicit guidance to recognize how their linguistic and cultural experiences may be continuous or discontinuous with the nature and practice of Western science' [italics added] (p. 481). A basic tenet of multicultural education, explicit instruction draws students' attention to code-switching. Code-switching entails a recognition for when a shift between different practices, ways of communicating, or ways of knowing needs to occurs. For example, a teacher may ask a student to repeat a statement that they made using everyday language in scientifically appropriate terms. Instruction toward recognizing the shift between everyday language and scientific discourse would help make linguistic codes explicit. In this way, students would be supported in recognizing everyday language apart from scientific discourse towards crossing a boundary into science and learning when to use scientific language.

Other multicultural education theorists uphold the need for explicitness in instruction towards making content-matter learning accessible for students and border-crossings possible (Ladson-Billings 1995). Moving educators towards a deeper explicitness in science would include mapping the assumptions of science as a part of classroom instruction. This would entail applying James Banks' platform for a critical rereading of curriculum in 
multicultural education (Banks 1996) to science education. Rather than focusing solely on transformative knowledge, or knowledge that empowers students, explicit instruction in science would include learning about knowledge frameworks, or the epistemic bounds of science. While Banks does suggest an interrogation of 'how knowledge is created and how it reflects the experiences, values, and perspectives of its creators' (p. 339), he does not go beyond this to consider comparative frameworks for knowledge construction in science, and how students' ways of knowing may or may not connect. Nonetheless, explicating the frameworks underlying science as a part of instruction is integral to students being able to challenge or apply science for their own purposes.

In this way, clarifying the assumptions and bounds of science as a part of science instruction may facilitate border crossings for students. This is because the subculture of school and schooling may differ from students' home cultures. These cultural differences may be particularly exacerbated in science classrooms, where not only the subculture of school may differ from students' home cultures, but science may remain a subculture apart. Thus, taking a multicultural approach to make science explicit through instruction without marginalizing students' ways of knowing is particularly relevant for students whose worldviews and subcultures differ from the cultural values of school-based science.

Norman Lederman (2004) offers an instructional perspective focused on the tenets of nature of science, that may serve to frame science, its culture, and its limitations explicitly for diverse student groups. Though Lederman's work does not address cultural differences in science learning, he advocates for combining inquiry-based instruction with explicit instruction in NOS. Lederman proposes supplementing science instruction with understandings of NOS. Specifically, he proposes that it is possible and important to teach particular aspects of nature of science, namely:

Scientific knowledge is tentative (subject to change), empirically-based (based on and/or derived at least partially from observations of the natural world), subjective (theory-laden, involves individual or group interpretation), necessarily involves human inference, imagination, and creativity (involves the invention of explanations), and is socially and culturally embedded (influenced by the society/culture in which science is practiced). (Lederman 2004, p. 304)

Explicit instruction in NOS involves deconstructing science and framing science content matter within its epistemological framework. For example, NOS instruction would reframe science as a social process of knowledge production rather than a body of factual information. Framing science within its epistemological assumptions, through an instructional approach including inquiry, instructional congruency, and explicit instruction in NOS, would provide students with tools for the exploration of science on its own terms. These instructional approaches are also intertwined. Rather than implementing science instruction that challenges, marginalizes, and is "subtractive" to students' epistemic stances and worldviews, greater instructional congruency can be met with instructional approaches that provide opportunities for deconstructing science and the negotiation of worldviews. For example, integrating instruction in what science is may help students discern what it is not, and to recognize its possibilities and limitations of science as practice and as a way of knowing. This would involve debunking the authority of science and empowering students to deconstruct science for themselves. We argue that inquiry, combined with instructional congruency and explicit instruction in NOS, would engage students in the activities of science framed by the assumptions of science and prepare students to mediate science with other cultural ways of knowing, or learn to negotiate cultural borders. By supporting diverse children in developing explanations through grappling with 


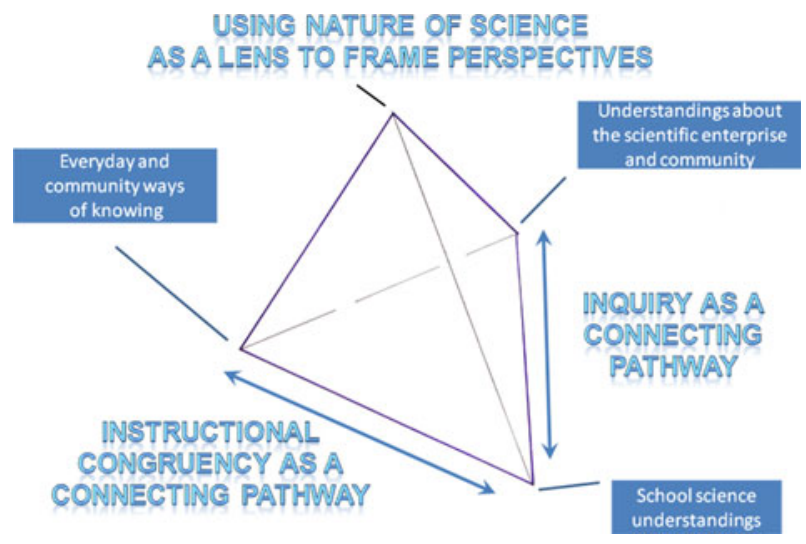

Fig. 1 Instructionally congruent inquiry-based instruction framed by explicit guidance in NOS

data, and connecting their explanations to scientific ones, this practice will give children opportunity to develop critical ways of thinking that will later serve them well.

An instructional emphasis on NOS may facilitate students' abilities to navigate between their own understandings, school science, and the scientific enterprise (see Fig. 1 below). Instructional congruency, for example, uses linguistic scaffolding to increase the accessibility of science during instruction. This approach, combined with NOS, would also frame the culture, norms, and assumptions of science. Explicit instruction in NOS offers a pathway for explaining how science influences day-to-day life and its potential limitations. Inquiry offers an instructional approach to bridge school science and the activities, context, and culture of the scientific enterprise. The possibilities and limitations, or ramifications, of these scientific ways of knowing can be made possible by explicit instruction in NOS. Instructionally congruent inquiry-based instruction, combined with explicit instruction in NOS, may provide important opportunities for non-mainstream students in negotiating differences between their lifeworlds, school science, and the scientific enterprise. Along the lines of collateral learning and a "both/and" instructional approach, this combined approach does not seek to challenge students' ways of knowing, but rather, provide tools for better understanding scientific ways of knowing.

This combined instructional approach may increase the accessibility of science and offer affordances to students challenged by border-crossings into science. For example, explicitness about scientific knowledge being 'subject to change' may facilitate student understanding of the scientific process of knowledge production. For example, a teacher can draw on examples that demonstrate changes in theories. This understanding may offset views of science as a fixed "truth" to accept and provide opportunities for students to negotiate understandings about science as an evolving field in which they, too, can participate. Explicitness about science being 'based on and/or derived at least partially from observations of the natural world' may in turn ground scientific learning in everyday life situations for students. This would provide space for student agency as active participants observing and making sense of the world around them. Explicitness about science being 'theory-laden, involves individual or group interpretation' may demystify power-relations in scientific knowledge construction. Within an instructional setting, this approach may invite a process of negotiating and accepting alternative understandings. Explicitness about science involving the 'invention of explanations' may foster the participation of diverse student groups. Rather than challenging students' cultural ways of knowing, this approach 
would boost student agency in making sense of science and the natural world as they attempt to make their own explanations. Finally, explicitness about science being 'socially and culturally embedded' may help students frame science as a cultural way of knowing with its own language, processes, and customs. This in turn, may help bolster students with agency to participate in science, while retaining their own cultural understandings and ways of knowing. Part of this includes demystifying how science is constructed and repositioning science as another way of knowing. This approach acknowledges that there are different cultural ways of knowing, science being one of them. The following section considers actualizing this instructional approach in classrooms serving diverse student groups.

\section{Classroom use of this instructional approach and student responses}

Science education researchers provide an extensive literature base related to enhancing inquiry-based instruction with NOS (e.g., Schwartz, Lederman, and Crawford 2004). The implementation of this instructional approach aligns with reforms in science education, where students are engaged in inquiry and the activities of science. Lederman (2004) explains that explicit instruction in NOS means bringing components of NOS to light during discussions about the practices of science. These conversations stem beyond conversations about science content matter or practice; rather, they frame the assumptions behind practices and the content that is then derived from those practicing science. Lederman upholds the importance of discussions about NOS being student-centered and co-constructed with students, rather than teacher-directed. This includes repositioning the teacher as a facilitator of learning rather than only a source of knowledge (Crawford 2000).

Explicit instruction in NOS can also integrate with and enhance multicultural education practices (see Table 1). Within the instructional congruency framework, an inquiry-based instructional approach already assumes a sharing of scientific authority and student-centered learning. Moreover, linguistic scaffolding to enhance meaning and the use of native and everyday language in the classroom increases the accessibility of science content-matter instruction. Greater context and relevancy are created by drawing on students' diverse cultural experiences and materials. These combined practices, focus on preparing students to appropriate scientific understandings. The added component of explicit instruction in NOS introduces the cultural components of science and frames it within its own assumptions. This instructional approach may help support students in accommodating competing worldviews and understandings toward maintaining a collateral, rather than challenged, worldview.

Table 1 Instructional congruency enhanced with NOS

\begin{tabular}{|c|c|}
\hline Instructional approach & Features \\
\hline $\begin{array}{l}\text { 1. Sharing of scientific } \\
\text { authority }\end{array}$ & $\begin{array}{l}\text { Student-centered approach; assumed } \\
\text { by inquiry }\end{array}$ \\
\hline 2. Linguistic scaffolding & $\begin{array}{l}\text { Increases accessibility of content- } \\
\text { matter }\end{array}$ \\
\hline $\begin{array}{l}\text { 3. Use of everyday language } \\
\text { in the classroom }\end{array}$ & $\begin{array}{l}\text { Increases accessibility of content- } \\
\text { matter }\end{array}$ \\
\hline $\begin{array}{l}\text { 4. Use of diverse cultural } \\
\text { experiences and materials }\end{array}$ & $\begin{array}{l}\text { Draws on students' everyday lives and } \\
\text { lifeworlds }\end{array}$ \\
\hline 5. Explicit instruction in NOS & $\begin{array}{l}\text { Introduces cultural components of } \\
\text { science and frames science within its } \\
\text { assumptions }\end{array}$ \\
\hline
\end{tabular}


Glimpses of the implementation of this combined instructional approach are shown in findings from our recent case study of a 5th grade bilingual classroom. The dual-language classroom, serving students at varying degrees of English language proficiency (ELP), was situated in a diverse urban middle school. Students in this classroom came from mainly Puerto Rican backgrounds, with some students in the classroom being recent immigrants. Thus, this classroom was not representative of the overall demographic composition of the school. In this classroom, the teacher, Monica, who had already practiced instructionally congruent approaches to her teaching, was implementing a series of lessons from the Fossil Finders Project, an inquiry-based instructional unit focused on NOS content and investigating the environment of the past using fossils as evidence. This classroom thus served as a case of bringing together the instructional approaches theorized. Monica's students participated in observing, identifying, and measuring fossils in scientific samples. Her students then entered these data into an online database, where they would be able to see the congregate data of their classroom, as well as the data of other schools involved in the project. Using these data, the students made inferences about their local environment during the Devonian period. During the implementation of the curriculum, Monica made repeated references to how students were modeling the authentic activities of scientists. The following transcript segment provides a concrete example of how a teacher might embed explicit components of NOS into inquiry-based instruction that also had components of instructional congruency. In this excerpt the teacher, Monica, carries out the National Academy of Sciences (1998) 'Proposing Explanations for Fossil Footprints' activity, which is an introductory part of the Fossil Finders Curriculum Unit that we refer to as 'Tricky Tracks.'

Monica: [About the Tricky Tracks activity] We don't have any evidence that shows that the tracks took place at the same time. Who here has a dog?

Students: [A few murmurs]

Monica: Okay. Did you ever take your dog walking and all the sudden they want to sniff and sniff and sniff and you're like, oh, another dog's been here?

Raul: $\quad$ Yeah

Monica: $\quad$ Could it be possible that one dinosaur came, walked around, took off and left the big tracks, let's say, and then maybe the little dinosaur came and sniffed around the tracks of the big dinosaur... and then flew away?

Students: [Murmuring]

Monica: $\quad$ That could be another take on what's happening. Or they both could have been walking, they could have been walking dinosaurs both of them and maybe that, the how do we say it, the petro... how do we say it?

Students: [overlapping] Petroteronodon...

Monica: Monica: Flew down and got the little dinosaur and took him away!

Researcher: It's actually Pterow-daactyl.

Monica: Oh, that's how you say it?

Students: [Repeating pronunciation]

Monica: Thank you, Researcher. [To students] Miss Monica doesn't want to misinform you.

Monica: But couldn't that have happened? Both dinosaurs heading toward the same place? The same food source? Maybe there's water there? There's vegetation...? That's something else that could have taken place. 
Monica: $\quad$ That's what I wanted you to see... different perspectives, different ways that you can view the Tricky Tracks, okay? And I want you to think back, do you remember... a [recent] question [we had] that said: "if scientists all have the same facts, how come they have different theories on what may have happened to dinosaurs?', '...

If they all have the same facts, why do they have different theories, remember we said it was different stories? This is the perfect example of how we can have the Tricky Tracks, the same facts, the same observation, but yet we are making different inferences, right? Different takes on what could have been.

(Transcript of Monica Vittorio's classroom, October 6th, 2008 at 57:12:00, lines 1-17)

Though she takes a lead role in facilitating the class discussion in this brief exchange, Monica demonstrates use of cultural congruency and explicitness about the nature of science. First, Monica references the need for evidence to construct an explanation. She states 'We don't have any evidence that shows that the tracks took place at the same time'. She then proceeds to tie this concept to students' knowledge and understanding about dogs. For example, in building on an example of how dogs may stop to sniff, she drew on students' everyday lives. Monica further shares authority, albeit not particularly scientific, when trying to pronounce the word 'pterodactyl'. In this way, she welcomed the participant observer approach that we, as researchers, took on in her classroom. Moreover, she repositions herself as a learning facilitator, rather than the source of knowledge.

Monica then proceeds to recall some of the possible explanations that students had come up with about the Tricky Tracks scenario. She refers to the multiple possible explanations of the Tricky Tracks activity as 'different perspectives, different ways you can view [them]' and 'different takes on what could have been'. This relates to the interpretive and creative components of NOS. She also points out that the activity relates to a question that they'd already seen about why scientists have different theories. To scaffold the concept of scientific theories, Monica calls them 'stories'. In this way, students can better connect to what is being discussed. These early findings support some aspects of this instructional approach, implemented in a staggered fashion. However, they do not fully illustrate a combination of all three components simultaneously. Nonetheless, this primary example illustrates the extent to which instructional approaches can be merged even in the context of more traditional large-group setting. Further, within this instructional episode, Monica provided scaffolding for students to consider how scientists think science, or may have different ideas, how they do science, or need evidence to construct explanation, and the language that they use, or use terms to identify species. This instructional approach begins to set the stage for students to learn to traverse spaces of cultural differences and diverse epistemic stances, in terms of understandings about science.

Nearly 2 months following this instructional episode, the first author purposively sampled five ELL students, and conducted interviews related to their views on science and science in relation to their everyday lives. Two students at higher levels of ELP and two students at lower levels of ELP were selected to be focus students, with girl and boy representatives in each group. A fifth student with high levels of ELP but demonstrating low performance on school testing measures was also selected. In these interviews, students shared their perspectives on what science is about and what scientists do. These responses indicated these children were beginning to understand the tenets of nature of science-that science is tentative, based on evidence, subjective, and involves human 
inference. Student replies also included examples of considering science as a way of knowing and bridging science learning between home ways of knowing and the classroom. For example, in response to the question, "Do all scientists do science the same way?," all five target students indicated that scientists did not do science the same way, but rather did different kinds of work. For example, Bianca responded "sometimes a scientist might do experiments and sometimes a scientist might do fossils," indicating an understanding that not all science is experimental. Brendan also commented on learning that scientists did other things than "experiment with chemicals." Raul acknowledged that some "scientists learn from past and figure out fossils" but others "might be learning about something else." Meanwhile, Paula commented "scientists have different stuff to do" and explained that scientists discover new things and have different pieces of data to support their discoveries. These views on science indicate emerging informed views about the diverse practices and fields of study that scientists may engage in and that science is a dynamic process, rather than an established set of facts.

In response to further interview questions, "do all scientists agree?" and "do all people agree with scientists?" student replies indicated differing, yet emerging informed understandings about the tentativeness and subjectivity of science. For example, Brendan stated "scientists have imaginations and disagree sometimes." This response considers scientists as active agents of constructing explanations based on their subjective perspectives. Paula also explained that sometimes scientists agree and sometimes they do not. This is because "scientists aren't the same." Moreover Paula stated that "people don't always think scientists are right," which begins to consider the positionality of science in relation to other ways of knowing. Raul suggested that sometimes scientists take guesses, for example, "if they're looking at a brachiopod or some other type of fossil." This suggests that viewpoints in science may be tentative. Raul also stated that "people don't always agree with scientists" but that "some people aren't right because they don't know more than the scientist." In this response, Raul positions scientific knowledge as contentious and also possibly having authority over other ways of knowing. Like Raul's statement, Bianca's response to the first question also suggested possible disagreement amongst scientists while interpreting data samples. "Somebody might think it's a segment of a brachiopod and another one doesn't. For instance, one scientist thinks it's this and the other thinks it's that." However, home-based views shaped her understandings that not all people agree with scientists. Bianca explained "one time I was at home and my brother started talking about scientists and what they were doing and my dad said that they were wrong and that not all people agree with scientists and what they do." In this statement, Bianca positions scientific knowledge as not always having authority, based on family views. Together, these statements point to student views of the tentativeness and subjectivity of science in relation to their understandings about science and everyday lives.

With respect to how science may connect to students' everyday lives, we asked students how they think what they learn in class relates to what they do outside of school. In their replies, the five target students commented on similarities and differences between classroom science learning and their experiences with science in out-of-school settings. Alyssa, for example, commented on the similarities of the purpose of science in both settings. In her response, she stated "science class similar to life because you discover new things every day." In this sense, she commented on the processes of learning in both settings. Paula commented on science content-matter learning as being bounded by the classroom setting and experiences with the following statement, "At home, rocks don't look like fossils." Bianca, on the other hand, considered content-matter spanning between both settings and how she had found fossils in the past. "There's a lot of fossils everywhere 
and there's rocks and one time I picked one up and there was a shell-shape in it." She followed up on this comment by situating school as a place to learn more about science content-matter with the statement, "my parents don't know a lot about fossils and I can learn it here." Raul considered the transferability of school science content-learning across contexts in describing how new knowledge could be applied in other settings. For example, with respect to using science knowledge outside of school, Raul explained, "if you find a rock you can describe it." Together, these responses illustrate students making connections between school science learning and their lifeworlds, framed by the context of an authentic investigation where students participated in the activities of science.

These interview responses indicate students viewing science as a particular way of knowing, rather than solely content-matter. Though these ways of knowing convey takenfor-granted Western modern values, they also provide a framework within which scientific knowledge can be situated. Recognition of the cultural aspects of science, through explicit instruction in NOS, may provide students with a framework in which they are able to place the pieces of scientific knowledge. While some students demonstrated the ability to connect science processes and content with their everyday lives, others considered how science remained apart from their day to day lives. With these understandings, it can be argued that students may begin to consider how their everyday and cultural understandings may or may not align with scientific ways of knowing and the importance of making NOS explicit to students through instruction.

Student responses to interview questions are also indicative of target students having some understandings related to the diverse approaches used in science and components of NOS. For example, students commented that scientists used various approaches to go about their work, that science included interpretation and inference-making, and that scientists possibly disagreed on what they were finding. From a cultural perspective, knowledge about the subjectivity tentativeness of science may reposition its assigned authority over other cultural ways of knowing. Moreover students shared views that people did not necessarily always agree with scientists, though for different reasons. Across these interview responses, students did not yet indicate understandings related to the socially and culturally embedded components of NOS; yet their preliminary understandings of the tentative and subjective components of science may indeed, prepare them to consider science across different cultural spaces in the future.

This is particularly relevant in school settings where science teaching may focus primarily on test preparation and passive learning. For example, focus students in this study initially described science as "reading out of a book" and "listening to their teacher" prior to engaging in authentic scientific research. Traditional and test-preparation approaches to science instruction are common in urban schools, which serve large numbers of students from backgrounds underrepresented in the sciences (Settlage and Meadows 2002).

Further barriers to science learning beyond the misrepresentation of the complex processes of science due to testing and test preparation include the inaccessibility of science through language differences and the taken-for-granted values about science as it is transmitted in schools. These barriers serve to diminish the opportunities for students to navigate between the cultural aspects of science, or NOS, and their everyday linguistic and cultural practices. The combined instructional approach makes an attempt to draw on students' background and cultural understandings and make explicit the culture of science. It further aims to increase the accessibility of science through linguistic scaffolding and open gateways to the practices of science by involving students in authentic scientific activities. It is important to, however, differentiate between an instructional approach that promotes accessibility of scientific activities and culture for underrepresented students 
from an instructional approach that forces enculturation in science. The difference here includes making clear what science is through explicitly discussing NOS and its limitations and providing students with opportunities to participate.

\section{Conclusions}

In this paper we argue for an integrated research-based instructional approach for supporting underrepresented students in learning science. Contrary to reforms that differentiate between learning science and learning about science, we believe that an instructional approach is needed that does both. While learning science would entail engaging in similar activities of scientists in the reduced form of school science, learning about science would entail learning how these activities and science content are framed by NOS. While inquirybased approaches afford greater opportunities for establishing greater relevancy in learning experiences, instructionally congruent inquiry coupled with explicit guidance in NOS may help frame science as a cultural way of knowing and provide students with opportunities to negotiate understandings about science with their own cultural perspectives. The features of inquiry, explicit instruction in NOS, and instruction congruency thus serve to complement one another and as a combined instructional approach, enhance the accessibility of science instruction for diverse student groups. In this way, combining these instructional approaches may provide promise and possibility for reaching students in science education, and underrepresented student groups, in particular.

Our call for explicit instruction in NOS aligns with that of Lederman (2004), but we go a step further, and combine this with the call of multicultural education theorists for instructional approaches that facilitate border-crossings. Making nature of science explicit throughout instruction is thus particularly relevant for students whose worldviews and subcultures differ from the cultural values of school-based science. Bolstering science teaching with explicit instruction in NOS may support underrepresented and ELL students in better framing their understandings of science and negotiating cultural border crossings in the future. Situating science within its epistemological assumptions would provide underrepresented and ELL students with a lens through which science may be explored on its own terms and in relation to students' cultural understandings.

Beyond making nature of science explicit, an effort to support students in making linguistic and cultural boundary and border-crossings in science learning would recognize science as a cultural way of knowing, adopting instructionally congruent learning strategies, and mapping out the epistemic stance of science. This instructional preparation will assist students in mediating between cultural differences in understanding between evaluating the potential and limitations of science. While inquiry-based approaches afford opportunities for establishing greater relevancy in learning experiences, instructionally congruent inquiry coupled with explicit guidance in NOS may help frame science as cultural way of knowing and provide students with opportunities to negotiate identities, epistemic understandings, and cultural practices in relation to science. As shown in Fig. 1, it is the convergence of these instructional approaches, framed through the lens of NOS, which provides promise and possibility for reaching students in science education, and underrepresented student groups, in particular.

For example, students can become active participants in the activities of science and a part of the knowledge construction process. Monica framed the work of scientists as careful and accurate, but still susceptible to human error. As a result, students rechecked their fossil measurements and were assertive about being accurate in their observations 
when Monica double-checked their work. These findings remain in the scope of this research, which considered the potential for the theorized instructional approach to be implemented in a classroom setting and its potential to facilitate student negotiation across cultural ways of knowing. Additional research is needed to learn specifically how teachers can give students from diverse cultural backgrounds the needed support in learning science. This includes researching professional development for teachers in the areas of instruction in NOS and instructionally congruent strategies.

Further, while explicit instruction in NOS coupled with culturally congruent inquirybased instruction may provide students with a means to negotiate understandings in science, there is currently little empirical evidence related to the use of this instructional approach with underrepresented students. Further researching how students may go about learning science and valuing science in their own lives in light of greater understandings about NOS is needed. Further, because a combined instructional approach that makes the assumption that science, a way of knowing and body of knowledge, cannot be taught through a reductionist way, future studies may consider how a combined instructional approach may not only enhance, but also possibly complicate how teachers may go about teaching science. This includes how teachers may or may not be able to mediate between school cultures, such as testing, language, and other taken-for-granted values and creating student possibilities to negotiate understandings about science. Thus, further investigation is needed to better understand how explicit instruction in NOS integrated into inquirybased instruction with instructional congruency may be brought into school settings, and in turn, afford underrepresented and ELL student groups greater connections to science learning and understandings of scientific culture.

Acknowledgments This material is based upon work supported by the National Science Foundation under Grant No. NSF 733233. Any opinions, findings, and conclusions or recommendations expressed in this material are those of the authors and do not necessarily reflect the views of The National Science Foundation.

Open Access This article is distributed under the terms of the Creative Commons Attribution Noncommercial License which permits any noncommercial use, distribution, and reproduction in any medium, provided the original author(s) and source are credited.

\section{References}

Aikenhead, G. S. (1996). Science education: Border crossing into the subculture of science. Studies in Science Education, 27, 1-52.

American Association for the Advancement of Science. (1990). Science for all Americans. New York: Oxford University Press, Inc.

Banks, J. (1996). Multicultural education, transformative knowledge, and action: Historical and contemporary approaches. New York: Teachers College Press.

Brown, J., Collins, A., \& Duguid, P. (1989). Situated cognition and the culture of learning. Educational Researcher, 18(1), 32-42.

Cobern, W. (1993). Construction of knowledge and group learning. In K. Tobin (Ed.), The practice of constructivism in science education (pp. 51-70). Hillsdale: Lawrence Erlbaum Associates.

Cobern, W. W., \& Loving, C. C. (2000). Defining "science" in a multicultural world: Implications for science education. Science Education, 85, 50-67.

Crawford, B. A. (2000). Embracing the essence of inquiry: New roles for science teachers. Journal of Research in Science Teaching, 37, 916-937.

Cummins, J. (2000). Language, power, and pedagogy: Bilingual children in the crossfire. Avon: Multilingual Matters Limited.

Driver, R., Asoko, H., Leach, J., Mortimer, E., \& Scott, P. (1994). Constructing scientific knowledge in the classroom. Educational Researcher, 23, 5-12. 
Erickson, F. (1993/1996). Transformation and school success: The politics and culture of educational achievement. In E. Jacob \& C. Jordan (Eds.), Minority education: Anthropological perspectives (pp. 27-51). Norwood, NJ.: Ablex Publishing Corporation.

Gutierrez, K., \& Rogoff, B. (2003). Cultural ways of learning: Individual traits or repertoires of practice? Educational Researcher, 32, 19-25.

Huber, R. A., \& Moore, C. J. (2001). A model for extending hands-on science to be inquiry based. School Science and Mathematics, 101(1), 32-41.

Jegede, O. J., \& Aikenhead, G. S. (1999). Transcending cultural borders: Implications for science teaching. Research in Science \& Technological Education, 17, 45-66.

Ladson-Billings, G. (1995). But that's just good teaching! The case for culturally relevant pedagogy. Theory into Practice, 34, 159-165.

Lederman, N. (2004). Syntax of nature of science within inquiry and science instruction. In L. Flick \& N. Lederman (Eds.), Scientific inquiry and nature of science: Implications for teaching, learning, and teacher education (pp. 301-317). Boston: Kluwer.

Lee, O. (2003). Equity for linguistically and culturally diverse students in science education: A research agenda. Teachers College Record, 105, 465-489.

Lee, O., \& Fradd, S. (1998). Science for all, including students from non-English-language backgrounds. Educational Researcher, 27, 12-21.

Lee, O., \& Luykx, A. (2006). Science education and student diversity: Synthesis and research agenda. New York: Cambridge University Press.

Lipka, J., Mohatt, G., \& The Ciulistet Group. (1998). Transforming the culture of schools: Yup'ik Eskimo examples. Mahwah, New Jersey: Lawrence Erlbaum Associates, Publishers.

National Research Council. (1996). National science education standards. Washington, DC: National Academy Press.

Nieto, S. (2004). Affirming diversity: The sociopolitical context of multicultural education. New York: Allyn \& Bacon Publishers.

Rosebery, A., Warren, B., \& Conant, F. (1992). Appropriating scientific discourse: Findings from language minority classrooms. The Journal of the Learning Sciences, 1(2), 61-94.

Schwartz, R. S., Lederman, N. G., \& Crawford, B. A. (2004). Developing views of nature of science in an authentic context: An explicit approach to bridging the gap between nature of science and scientific inquiry. Science Education, 88, 610-645.

Settlage, J., \& Meadows, L. (2002). Standards-based reform and its unintended consequences: Implications for science education within America's urban schools. Journal of Research in Science Teaching, 39, $114-127$.

Southerland, S. A. (2000). Epistemic universalism and the shortcomings of curricular multicultural science education. Science \& Education, 9, 289-307.

Warren, B., Ballenger, C., Ogonowski, M., Rosebery, A., \& Hudicourt-Barnes, J. (2001). Rethinking diversity in learning science: The logic of everyday sense-making. Journal of Research in Science Teaching, 38, 1-24.

Wenger, E. (1998). Communities of practice: Learning, meaning, and identity. New York: Cambridge University Press.

\section{Author Biographies}

Xenia Meyer is a post doctoral fellow of the Graduate School of Education at the University of California, Berkeley. At the time of writing this paper, she was a doctoral candidate in the Learning, Teaching, and Social Policy program at Cornell University and also involved with the Fossil Finders project. She received her Ph.D. in Science Education from Cornell University in 2010. Prior to initiating her doctoral work, she taught science to diverse and English language learning (ELL) students at an urban high school and engaged groups of students from K-12 grade levels in informal science learning experiences at the Exploratorium. Concurrently, she earned her master's degree in science teaching and credential for bilingual education at the University of San Francisco. Her work focuses on inquiry-based pedagogy, nature of science, sociocultural perspectives on science and science learning, differential school achievement, and multicultural education. Presentations related to this work have been given at the National Association of Research in Science Teaching and the American Educational Research Association.

Barbara A. Crawford is an associate professor of science education at Cornell University. She received her Ph.D. in Science Education from University of Michigan in 1996. Prior to earning her Ph.D., she earned a degree in microbiology and a masters degree in biology from the University of Michigan. Her knowledge of 
scientific research and science education is rooted in her experiences as a chemical process engineer and as a science teacher of 16 years in public schools. Her main area of research is inquiry-based pedagogy and nature of science, teacher knowledge and beliefs, science teacher education, and how to support diverse children in learning about what science is, and what science is not. She has served on the Editorial Board and as a reviewer for several journals, including Journal of Research in Science Teaching, Science Education, the Journal of Science Teacher Education, and International Journal of Science Education. She is presently Director of an NSF Materials Development and Research grant focused on engaging teachers and children in inquiry, nature of science and teaching evolution through the use of fossils as evidence. Her articles are published in JRST, Science Education, The International Journal of Science Education, Research in Science Education, among others. 